\title{
HOKKIEN AS A HERITAGE LANGUAGE OF CITIZENRY IN SINGAPORE
}

\author{
Jyh Wee SEW \\ National University of Singapore \\ clssjw@nus.edu.sg
}

Manuscript received 6 July 2020

Manuscript accepted 11 August 2020

*Corresponding author

https://doi.org/10.33736/ils.2393.2020

\begin{abstract}
In examining Hokkien as a heritage language in Singapore, this discussion hopes to contribute to an enriching of the perception of citizenship in an ever-evolving national narrative towards one people (Mathew, 2017). The Singapore Census of Population statistics indicate that $11 \%$ of ethnic local Chinese households speak Hokkien. Singaporean television serials and movies that use Hokkien as the medium of narration achieve encouraging viewership and box office ratings, hinting that Hokkien is understood, or appreciated by a significant number of the local population as a language of prominence. Therefore, since Hokkien holds a key to common Chinese Singaporean cultural memories, this paper contemplates if learning Hokkien could cultivate a collective resilience when balancing professional, and personal challenges. To this end, 冰冰 Show, a contemporary Taiwanese variety program available on YouTube, is used to evaluate the potential power of this language in nurturing citizenship.
\end{abstract}

Keywords: Heritage language; Hokkien proverbs; ethnocultural intelligence; multicultural literacy; Singapore citizenry

\section{Introduction}

Singapore has a rich dialect profile, even when one considers the Chinese community per se. A survey conducted in 2005 by the Statistics Department of Singapore showed that 277,910 persons aged 5 years or older spoke Hokkien in Singapore (Dept. of Statistics, 2010). This total amounts to $8.95 \%$ of the Singapore population of the same age group. In the ethnographic poll by the Census of Population in 2010, however, 238,843 out of 492,031 dialect speakers in Singapore reported speaking Hokkien (Sew, 2016). The decrease in the number of Hokkien speakers between 2005 and 2010 is alarming, and Li (2018) notes the increasing disappearance of Hokkien in Singapore in his discussion on translanguaging as a mode of communication in the multilingual societies.

The dwindling number of Hokkien speakers suggests a bleak sociolinguistic future facing the heritage language in Singapore (Chua, 2012). In offering his 
comparative cultural and political analyses between a local Hokkien film Money No Enough (钱不够用) and a Taiwanese film Tai ping tian guo (太平天国), Chua Beng Huat wrote poignantly (Chua, 2012, p. 64):

... the educated and successful speak only English and Mandarin in all social transactions and increasingly also at home, the marginalisation and suppression of Hokkien and its speakers are processes of internal colonisation ... Hokkien speakers in Singapore are condemned to a slow but certain silencing and eventual disappearance. The erasure of their histories in the collective memory of the Singapore nation because their past and participation in local history can no longer be communicated fully becomes more certain as each successive generation becomes less and less competent in the Hokkien language, to the vanishing point of total incompetence ... the language's demise all the more tragically, as fewer and fewer Singaporeans are able to understand the films, beyond the comic scenes, for want of linguistic competence.

Currently, the ability to speak the dialect of one's origin seems to be a concern of some local undergraduates. Such a conjecture is based on a recent enrolment of 41 tertiary learners in a student-driven Design Your Own Module initiative that teaches spoken Hokkien at the National University of Singapore (NUS NEWS, 2020). A study examining the social cultural traits and language attitudes of Hokkien and Foochow speakers in Sarawak informs that the ability to speak one's dialect is important to the Sarawakian Hokkiens. The 150 Hokkien participants of the study reported feeling embarrassed at their inability to speak the Chinese dialect (Ting \& Puah, 2015).

This discussion, nonetheless, claims that Hokkien ethnocultural intelligence remains relevant to the Singaporean society as the dialect contributes to original social schemata relevant for enriching the nation's multicultural heritage. Essentially, Hokkien contributes to the diversification of Singapore's ethnography, not least because it underscores ethnocultural practices such as Chinese hawker food, worship, folk ritual, as well as ethnic-communal celebrations including the Hungry Ghost Festival in Singapore. We begin the discussion by highlighting how Hokkien may broaden the horizons of English and Mandarin speakers in the diverse cultural environment of Singapore.

\section{Hokkien in Singapore}

The competitive edge of Singapore's workforce arguably stems from its bilingual language policy. In the national education system, there are three official mother tongue languages in Singapore that complement English, namely, Mandarin for Chinese, Malay for the Malays, and Tamil for the Indians. This linguistic combination equips a person with the skills to compete in a global economy that has English as a de-facto lingua franca, while maintaining a sense of rooted loyalty in one's Asian heritage (Wee, 2006). Official information is disseminated in Mandarin through the mass media in Singapore. For example, the afternoon and evening news for the 
Chinese-speaking communities are broadcasted in Mandarin on two free-to-air television channels, both managed by MediaCorp Singapore. While Mandarin is the official medium of dissemination, selected Chinese dialects occupy a segment in the mid-afternoon news broadcast on radio through Capital FM95.8, which involves a reading of news bulletins in Foochow, Hainanese, Hokkien, Cantonese, Teochew, and Hakka (Ang, 2017). Recently in July 2020, Capital FM95.8 included a Cantonese storytelling segment on Friday nights. While acknowledging the existence of other linguistic sub-groups symbolically on air, Hokkien faces devaluation since 1979:

Because the Chinese community in Singapore's early history was characterised to convince Chinese Singaporeans to replace their various dialects with Mandarin. This Speak Mandarin Campaign is re-launched annually, amidst pomp and fanfare, where the state reiterates the importance of speaking Mandarin. (Wee, 2006, p. 350)

The ban on dialect use was formalised in the interest of learning the mother tongue without any distraction from dialect influence (cf. Chua, 2012; Lee, 2016). We can imagine the silencing of other Chinese dialects by gauging Aboriginal English, often referred as rubbish English, in Australia. According to Malcolm (2007, p. 59), "aboriginal people have preferred not to be heard using their dialect in the company of the 'standard' dialect speakers" because they were told by the educators that they speak a wrong language.

The discriminatory sociolinguistic phenomenon reflects a linguistic hegemony in the local Chinese language situation. Even though dialects are officially discouraged, Hokkien has not retreated into total silence as the usage of Hokkien is traceable in the heartlands. Hokkien resides in the audiotopia of getai, and movie theme songs in Singapore (Liew \& Chan, 2013). Getai, which literally means a song stage, is part of the folk performance during the Hungry Ghost Festival. Local and foreign performers sing, banter, and occasionally drag in the company of a live band on stage (Sew, 2016). Hokkien theme songs, on the other hand, have become a defining element in the films of local directors such as Roystan Tan, and Jack Neo (cf. Liew \& Chan, 2013). It is, thus, not surprising that Hokkien has found its voice in the local silver screen. For example, Money No Enough, a 1998 movie directed by Jack Neo, used Hokkien as the medium of narration. The characters in the movie exploited what Pennycook (2007) calls cultural-communicative efficacy to win the local audience's hearts. Worthy of our attention, the idiosyncratic use of Hokkien speech and cultural norms transformed a seemingly moribund dialect into a lucrative theatrical medium. The movie has grossed $S \$ 5.8$ million at the box office and sold another 70,000 pieces of video compact discs (VCDs) in the local entertainment market.

The commercial success of Money No Enough revealed that Hokkien is a bankable sociolinguistic choice in Singapore. For one thing, Hokkien captures common heritage memories, especially in reclaiming a Chinese-Hokkien identity based on linguistic origins. To this end, the National Heritage Board, through the cataloguing of Singapore proverbs, completed a project that recorded dialectal proverbs and wise sayings. As a result, a collection of 15 chapters based on the 
languages spoken in Singapore were published, and these included Cantonese, Hakka, Hokkien, Malay, Mandarin, Tamil, and Teochew (Nayak \& Rao, 2013). The non-Chinese researchers have contributed to the revitalisation project of Singaporean Hokkien, initiating the restoration of Hokkien as a heritage language in Singapore's ethnocultural nexus. In salvaging his Hokkien memories, Kuan (2014), who sees the need to revitalise Singapore Hokkien, published a picture book containing Hokkien phrases entitled My picture book of dialect which affirmed that educated individuals are aware of the grave reality of their dialects disappearing in time. Tapping on social media, Kuan (2014) also teaches spoken Hokkien by posing occasional video on phrases from his book through the Facebook account Sibey Nostalgic.

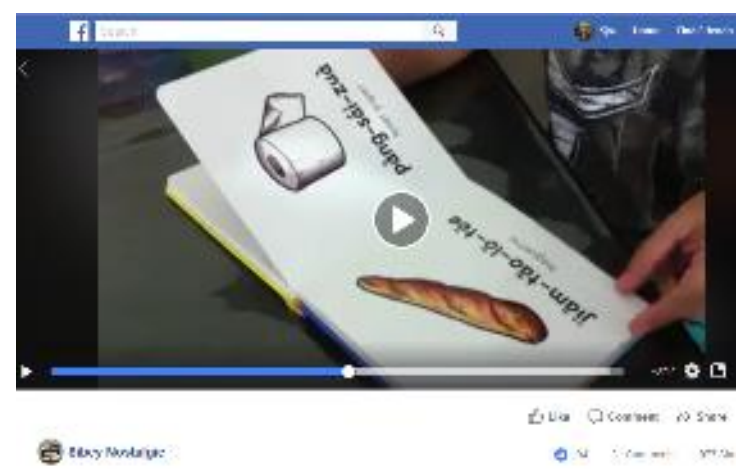

Figure 1. Screenshot of Sibey Nostalgic in Facebook

As illustrated in Figure 1, the attempt to teach Hokkien phrases via Facebook is a commendable strategy to attract young speakers because Hokkien audio materials are scarce in Singapore. Apart from the movies that Jack Neo and other directors produced, there are only a handful of YouTube videos where Hokkien spoken in Singapore is audible. Notably, Singapore Telecommuncations Limited (Singtel), the largest mobile network operator in Singapore, commissioned and uploaded eight video clips entitled "Are You Hokkien?" to YouTube in 2014.

In exploring the dialect of origins as an identity marker, the Sarawakian Foochow and Hokkien speakers tend to show preference for multifaceted identity associations as they consider ethnic identity as only one of their many identities (Puah \& Ting, 2017). In the same vein, Mathew (2017) reminds that many Singaporeans are looking forward to a collective definition of one's identity beyond the individual inherited markers. This is simply because a stereotypical reduction by virtue of one's race is not a popular categorisation.

Enlightened multicultural students can emerge from building multicultural educational systems that incorporate the values and perspectives of different groups of people found in that society and who are contributing members of it. This approach is far from seeing multiculturalism as an "extra" in the classroom or to be fitted into the curriculum as and when time permits, leading student to form impressions of ethnic or religious groups based on snapshots. Students can be encouraged to see that inter-ethnic 
ties are not separate from the broader system of social relations operating in society, moving away from the fallacy of particularism.

(Matthew, 2017, p. xxv)

In the interest of conceiving a well-rounded understanding of citizenry, Hokkien proverbs, as a resource, may be incorporated in the planning of civic and national education, not least because the proverbs are rich in the values of sociability (see the following sections). Such exploit of the proverbs in refining the citizenry knowledge is in line with the recent efforts of Senior State Minister, Dr Janil Puthucheary who promoted the sharing of respectful conversations on citizenship experiences in Channel News Asia (Chia, 2018).

Specifically, this discussion explores the ways in which the local speech community may be reinvigorated with a sense of camaraderie from using Hokkien as a medium of intra- and interpersonal communications. In an effort to fortify a mindset that supports each other as fellow countrymen, we wonder if Hokkien equips its speakers with the resilience to face challenges, such as the economic crisis, and job-related hardships brought about by COVID-19. This discussion explores the potentials of Hokkien schemata to foster personal commitment for the common good. Armed with optimism, we want to identify the Hokkien ethnocultural intelligence that galvanises civility amongst its speakers. Eventually, we hope to see aspects of Hokkien proverbs generating a positive ripple effect in everyday life. This would underscore the belief that the Hokkien proverbs is a sociolinguistic instrument that enhances positivity against what Lakoff (2005) calls the culture of victimisation or the blame game, especially when one faces major ordeals, for example, life-threatening health issues, pandemic-related restrictions and retrenchment.

\section{Hokkien from the Bing Bing Show}

The data under analysis are a set of Hokkien proverbs identified by an experienced and learned Taiwanese artist, Bai Bing Bing (白冰冰) in a Hokkien variety show she hosted. In the competitive Taiwan television world, Bai's variety show, which aired weekly in the afternoon, have raked in top ratings (中視新聞, 2018). Based on the YouTube video clips, Table 1 contains a selection of 12 Hokkien proverbs shared by 白冰冰 in her 冰冰 Show. 
Table 1

Hokkien proverbs derived from 冰冰 Show (2017)

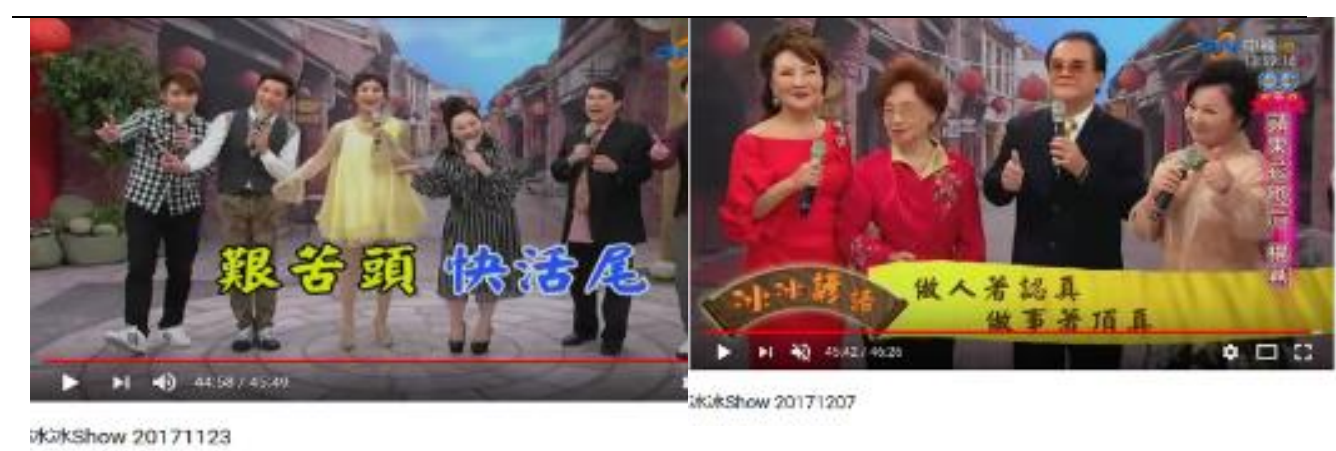

Kan-khóo-thâu; khuìnn-uáh-bué.

Bitter start; sweet ending (冰冰 Show, 2017, Nov. 23)
Tsò-lâng tiòh jīn-tsin; tsò-sū tiòh tíngtsin.

Showing your remarkable self; performing with the best effort (冰冰

Show, 2017, Dec. 07)

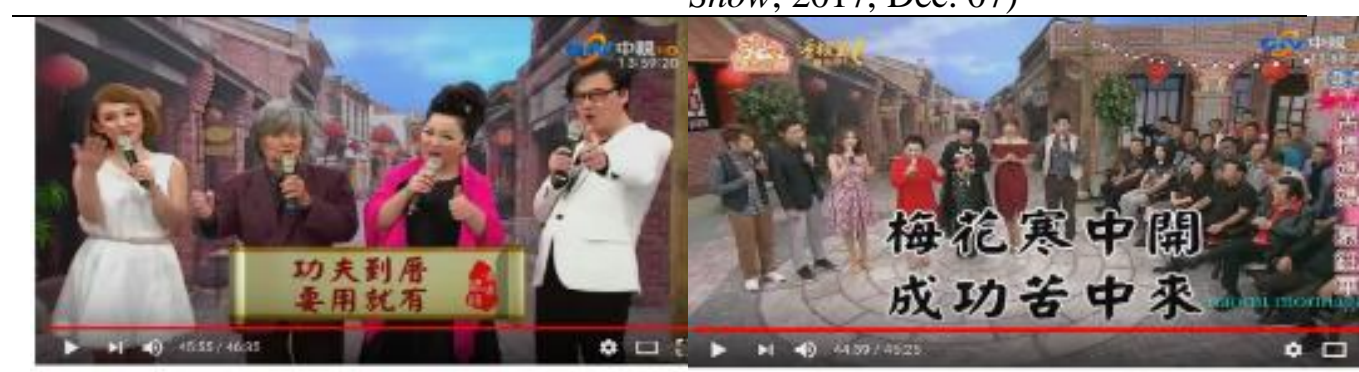

Wasshow 20171215

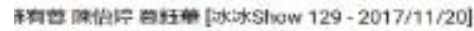

Kang-hu kàu-tshù; beh-iōng tiòh-u. Be prepared for future (冰冰 Show, 2017, Dec. 15)

Muî-hue hân-tiong khui; sîng-kong khóo tiong lâi. Blossoms bloom in cold; success comes with struggle (冰 冰 Show, 2017, Nov. 20).

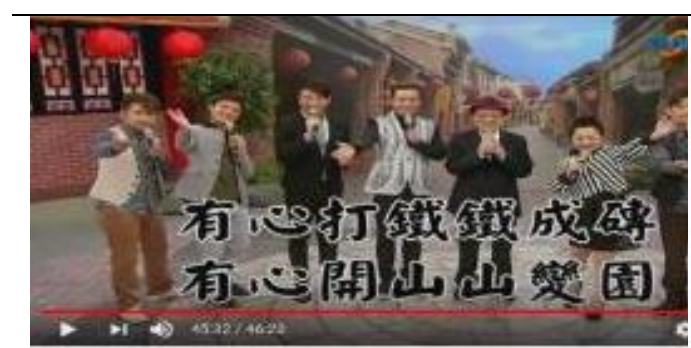

kiks show 20171117

$\bar{U}$-sim phah-thih thih sing tsng; $u$-sim khui-suann suann piàn hîg.

Iron and mountain can be village and farm if willing (冰冰 Show, 2017, Nov. 17) atcidsshow 20171204

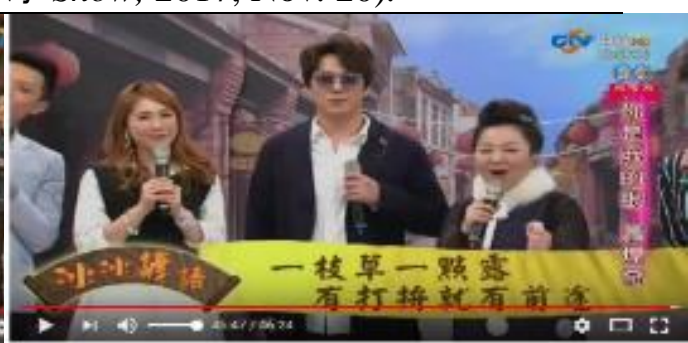

Tsit-ki tsháu tsit-tiám lòo; $\bar{u}$ phahpiànn tiò-ü tsiân-tôo.

Each blade of grass begets a dew, great effort begets the future (冰冰 Show, 2017, Dec. 04) 


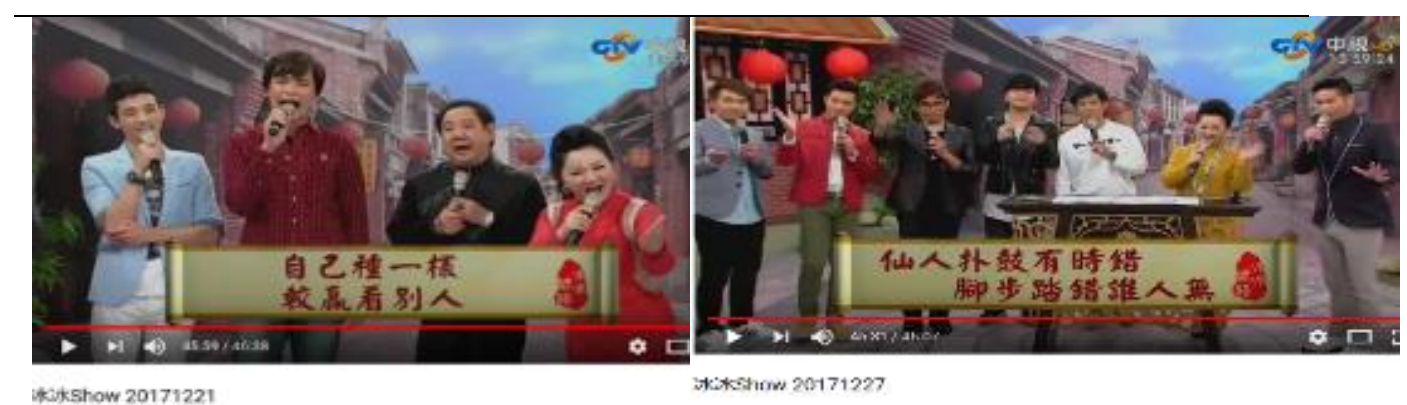

Wijshow 20171221

Sian-lâng phah-kóo ū-sî tshò; kha-pōo

Ka-kī tsìng tsit-tsâng; khah-iânn khuànn pát-lâng. Growing in the our lawn. Yearning nothing next door ( 冰 冰 Show, 2017, Dec. 21) táh-tshò siánn-lâng bô. Deities might miss a drum beat; human may miss a $\underbrace{}_{\rightarrow \infty \text { andus }}$ step (冰冰 Show, 2016, Dec. 27)

\section{anstratikshow 20171211}

step (伓 Show, 2016, Dec. 27)

Sann-pah lák-tsáp hâng; hâng-hâng tshut tsōng-guân. In each of the three hundred and sixty five skills, a leader exists (冰冰 Show, 2017, Dec. 18)

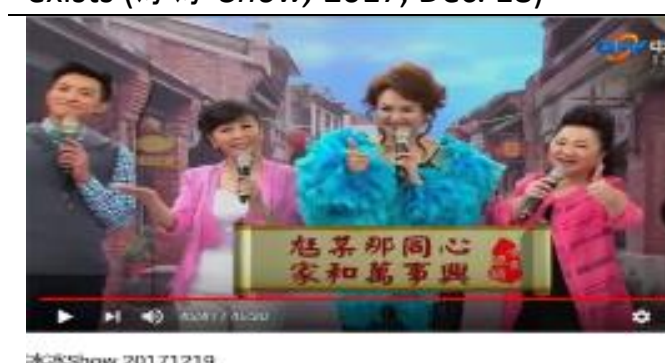

AcBssshow z0171219

Ang-bóo nā tâng-sim; ka-hô bān-sū hing.

Collaborative husband and wife makes a harmonious home (冰冰 Show, 2017, Dec. 19)
$\bar{M}$-pat jī tshiánn-lâng khuànn; $\bar{m}$-pat lâng liáu tsit-puànn. Illiterate hires a reader; solitary losses half of the battle (冰冰 Show, 2017, Dec. 11)

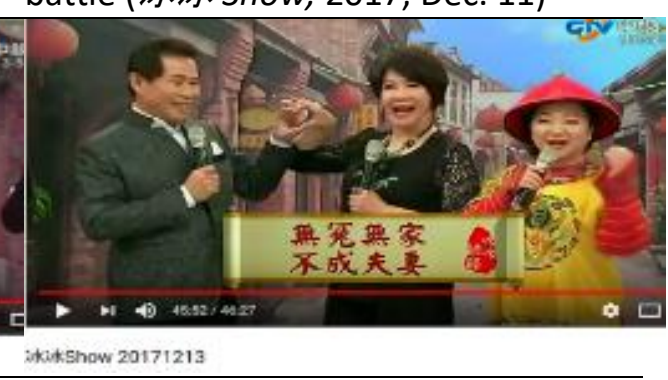

Bô-uan bô-ke; put-sîng hu-tshe. Small quarrel makes a couple (冰冰 Show, 2017, Dec. 13)

It is evident that the underlining morphosyntax of the data in Table 1 is a biphrasal construction. This prototypical construction consists of a prelude statement followed by a proposition statement. In other words, each proverb presents a preface that foregrounds the underlying message. Such a bipolar construction resembles a Malay pantun in that the poetic statement is accompanied with the actual message (Salleh, 2018; Sew, 2015a). The Malay pantun typically appears as a four-line verse with the first two lines foregrounding the actual intention of the last 
two lines (Salleh 1991; Sew, 1996). Where a poetic statement of a pantun could be semantically independent of the intended message the Hokkien proverb's prelude statement, however, forms an integral and coherent part with the proposition. Without the prelude premise, the proposition becomes a hanging phrase lacking the causal reasoning of a persuasive idiom and vice versa. In terms of composite design, the bi-phrasal proverbs are underscored by four types of constructions. The unique composite design in each type operates figuratively to connote the pragmatics of the common good. For our discussion purpose, we classify these composite designs into $\mathrm{H} 1, \mathrm{H} 2, \mathrm{H} 3$, and $\mathrm{H} 4$.

$\mathrm{H} 1$ consists of a prelude statement contradicts the proposition. Inferring from the vividness hypothesis (Gibbs, 1994), we highlight that the contradictory style of cross-referencing is a relevant strategy for conveying a richer image to address the subjective experience. The pragmatic contradiction lies with the phrases bitter head in the prelude contradicting sweet end in the proposition. In the second example of $\mathrm{H} 1$, the argument contradicts with husband and wife that symbolises marriage in the proverb. Both arguments in the prelude as well as the metonymic husband and wife in the proposition corroborate to denote family. Furthermore, the composite design in both examples exhibits the conventional discourse-pragmatic principle, namely, the definite reference (e.g. bitter head, argument) precedes the indefinite counterparts (e.g. sweet end, husband and wife) (Heine, 1997). Common sense suggests that the head (thâu) is more salient than the end (bué). Further, compared to husband and wife, the definiteness of argument is augmented with the iterative negation of (bô) in Hokkien (cf. bô-uan bô-ke in the second proverb of Table 2).

In $\mathrm{H} 2$, on the other hand, the prelude statement serves as a foreground that incrementally amplifies the message in the proposition. There are four examples of H2. The first example parallels the principles of becoming a remarkable person with that of performing a task superbly. In the second example, the blooming of cherry blossom entails the arrival of success. In the third example, a gradual development is observable in the expansive transformation of village from iron and farm to mountain. Lastly, the reference of husband and wife correlates with the notion of home. All the $\mathrm{H} 2$ examples indicate that the prelude statements serve as the pragmatic launch pads, so to speak, to conjure the contention of the underlying messages. We may understand the composite design of $\mathrm{H} 2$ with the compactness hypothesis that sees the use of metaphorical descriptions as a useful pragmatic strategy for partitioning the continuity of conscious experience into succinct references (Gibbs, 1994).

H3 uses a logical configuration that presents a unidirectional causal reasoning. The first example of $\mathrm{H} 3$ explicates that self-sufficiency trumps the yearning of others' possession. The second example correlates two phrases of logical equivalents that rhyme, namely, if one is illiterate one may hire a reader, and solitude is half of the battle lost. In the third example, a hardworking person who attains success is equivalent to the effort of an individual grass blade collecting a drop of morning dew by persevering through the night. Affirming the importance of skill-readiness, the fourth saying reminds us about the ease of performing a job if one is equipped with the required expertise. Comparatively speaking, we notice the 
similar logical configuration in Malay proverbs, e.g., kalau pandai meniti buih; selamat badan ke seberang (with skills, success follows), and kalau takut dilimbur pasang, jangan berumah di tepi pantai (those afraid of smoke should not stay in the kitchen) (cf. Daipi, 2018).

Unconstrained by a singular template of composite design, $\mathrm{H} 4$ appropriates either a contradictory configuration, an incremental development, or a causal-logical equation. The first example suggests that a leader is bound to exist in every task. Divine errors are exploited in the second example to lessen the adverse impact of miscalculations the humans make. The motion thrives on a cultural logic that even the supreme deities err. The inexpressibility hypothesis in Gibbs (1994) explicates that figurative language is used to manage difficult ideas. While Gibbs' (1994) difficult notions refer to swiftness, suddenness or ungraspability), the difficult thing in Hokkien is about offering face-threatening remarks, and negation. As such, a composite design based on a logic of causal reasoning may mitigate impoliteness by appealing to common sense in Hokkien. The selected 12 sayings are, thus, classifiable into the four idiomatic patterns presented in Table 2.

Table 2

Pragmatic configuration of Hokkien proverbs

\begin{tabular}{|c|c|c|}
\hline Semantic types & Hokkien sayings & $\begin{array}{l}\text { English glosses } \\
\end{array}$ \\
\hline $\begin{array}{l}\text { H1: } \\
\text { Contradictory } \\
\text { configuration }\end{array}$ & $\begin{array}{l}\text { 1. Kan-khóo-thâu; khuìnn-uáh- } \\
\text { bué } \\
\text { 2. Bô-uan bô-ke; put-sîng hu- } \\
\text { tshe }\end{array}$ & Small quarrel makes a couple \\
\hline $\begin{array}{l}\text { H2: Incremental } \\
\text { configuration }\end{array}$ & $\begin{array}{l}\text { 1. Tsò-lâng tióh jīn-tsin; tsò-sū } \\
\text { tiòh tíng-tsin } \\
\text { 2. Muî-hue hân-tiong khui; } \\
\text { sîng-kong khóo tiong lâi } \\
\text { 3. Ū-sim phah-thih thih sîng } \\
\text { tsng; u-sim khui-suann suann } \\
\text { piàn hn̂g } \\
\text { 4. Ang-bóo nā tâng-sim; ka-hô } \\
\text { bān-sū hing }\end{array}$ & $\begin{array}{l}\text { Showing your remarkable self; } \\
\text { performing with the best effort } \\
\text { Blossoms bloom in cold; } \\
\text { success comes with struggle } \\
\text { Iron and mountain can be } \\
\text { village and farm, if willing } \\
\text { Collaborative husband and wife } \\
\text { makes a harmonious home }\end{array}$ \\
\hline $\begin{array}{l}\text { H3: Logical } \\
\text { consequence }\end{array}$ & $\begin{array}{l}\text { 1. Ka-kī tsìng tsit-tsâng; khah- } \\
\text { iânn khuànn pát-lâng } \\
\text { 2. M̄-pat jī tshiánn-lâng } \\
\text { khuànn; mi-pat lâng liáu tsit- } \\
\text { puànn } \\
\text { 3. Tsit-ki tsháu tsit-tiám lòo; ū } \\
\text { phah-piànn tióh-ū tsiân-tôo } \\
\text { 4. Kang-hu kàu-tshù; beh-iōng } \\
\text { tiòh-ū }\end{array}$ & $\begin{array}{l}\text { Grow it in the lawn; } \\
\text { nothing next door we yearn } \\
\text { Illiterate hires a reader; } \\
\text { solitary losses half of the battle } \\
\text { Each blade of grass begets a } \\
\text { dew, } \\
\text { great effort begets the future } \\
\text { Be prepared for future }\end{array}$ \\
\hline $\begin{array}{l}\text { H4: Cultural } \\
\text { rhetoric }\end{array}$ & $\begin{array}{l}\text { 1. Sann-pah lák-tsáp hâng; } \\
\text { hâng-hâng tshut tsōng-guân }\end{array}$ & $\begin{array}{l}\text { In each of the three hundred } \\
\text { and sixty five skills, a leader }\end{array}$ \\
\hline
\end{tabular}




\section{exists}

2. Sian-lâng phah-kóo ū-sî Deities might miss a drum beat; tshò; kha-pōo táh-tshò siánn- human may miss a step lâng bô

This discussion differentiates ethnocultural intelligence from linguistic intelligence in that the former represents the voice of the subjugated group whereas the latter is the typical mainstream intelligence (cf. Nolan, 2004). The data in Table 2 demonstrate that maintaining amicable interpersonal relationships is a tenet undercutting all the Hokkien proverbs. Arguably, sociability is the main code of civility underscoring communal well-being, not least because the power of renegotiation is reinstated in a courteous conversation be it about the family, marriage, neighborhood, society, and leadership issues (Sew, 1997). Furthermore, Hokkien sociability as a quality is also traceable to a study conducted at University of Sarawak Malaysia. It is reported that the solidarity traits of Hokkien speakers is rated as informal compared to Mandarin speakers (Ting \& Puah, 2010).

Table 2 presents an ethnocultural window to the Hokkien way of being, as it were. The Hokkien proverbs are ingrained with ethnocultural values befitting a harmonious speech community (cf. Sew, 2015b). In the following section, we examine the potential contribution of this dialectal heritage in the nation building narrative of one people.

\section{Discussion}

Thus far, the alternative worldview appropriated by the Hokkien proverbs presents a spectrum of celestial, communal, deductive, inductive, logical, and superiorsubordinate relations. Through these contemplations of Hokkien intelligence the speakers may procure the cognitive capacity to develop a flexible logic of causal reasoning robust in resilience. In this respect, the Hokkien proverbs pose mirror images of a series of social practice (Wee, 2011, 2018) suitable for reinterpreting livelihood. Indeed, the proverbs are schemata appropriate for developing a positive citizenry mindset. We argue that the Hokkien proverbs make a valuable resource for boosting the confidence of vulnerable social groups, which include care givers, children with special needs, patients, senior citizens, unemployed, etc. By developing a robust self-confidence, the resistance against any domestic, and workplace frictions is, thus, strengthened.

The corrosion of resilience is manifested in challenging times such as the threat of a pandemic. In the event of a conflict and discontentment, however, the ability to rectify one's error, and improve on one's shortcomings becomes precious survival skills. At the very least, a decent citizen is expected to observe civility by withholding any bad intentions that one might have otherwise done (cf. Lakoff, 2005 , p. 25). We suggest that the appreciation of the proverbial schemata may mitigate, if not neutralise, the negative perceptions typical of the blame game. That even the deities make mistakes offers the Hokkien listeners the courage to reboot and recalibrate the less than favourable existence in the face of precariousness. Exploiting divinity in this way adds to the significance of Hokkien proverbs as a 
powerful verbal weapon. If incorporated to civic education, the Hokkien proverbs may offer valuable schemata complementing the mainstream adages.

This discussion examines further the mission statements of the Ministry of Culture, Community and Youth (MCCY), which explicate that the deployment of heritage is one of the strategies for attaining the following outcomes:

pursue our aspirations for fulfilling lives;

be a gracious society built on mutual appreciation and trust;

have a strong sense of belonging to Singapore, our home.

(MCCY, 2018)

The intended outcomes outlined in the mission statements contain at least two grand values that MCCY strives to achieve, namely, aspirations, and mutual appreciation. In alignment with the MCCY's action plan, cultural literacy educators may consider presenting the Hokkien proverbs as a resource applicable for maintaining the social ideals of nation building.

Table 3

Aligning the Hokkien proverbs with the social ideals

\begin{tabular}{|c|c|}
\hline $\begin{array}{r}\text { Aspirations } \\
\end{array}$ & Mutual appreciation \\
\hline $\begin{array}{l}\text { Kan-khóo-thâu; khuìnn-uáh-bué } \\
\text { Bitter start; sweet ending }\end{array}$ & $\begin{array}{l}\text { Bô-uan bô-ke; put-sing hu-tshe } \\
\text { Small quarrel makes a couple }\end{array}$ \\
\hline $\begin{array}{l}\text { Tsò-lâng tiòh jīn-tsin; tsò-sū tióh tíng-tsin } \\
\text { Showing your best self; } \\
\text { performing with the best effort }\end{array}$ & $\begin{array}{l}\text { Sann-pah lák-tsáp hâng; hâng- } \\
\text { hâng tshut tsōng-guân } \\
\text { In each of the three hundred } \\
\text { and sixty five skills, a leader } \\
\text { exists }\end{array}$ \\
\hline $\begin{array}{l}\text { Kang-hu kàu-tshù; beh-iōng tióh-ū } \\
\text { Be prepared for future }\end{array}$ & $\begin{array}{l}\bar{M} \text {-pat jī tshiánn-lâng khuànn; } \bar{m} \text { - } \\
\text { pat lâng liáu tsit-puànn } \\
\text { Illiterate hires a reader; } \\
\text { solitary losses half of the battle }\end{array}$ \\
\hline $\begin{array}{l}\text { Muî-hue hân-tiong khui; sîng-kong khóo tiong lâi } \\
\text { Blossoms bloom in cold; } \\
\text { success comes with struggle }\end{array}$ & $\begin{array}{l}\text { Ang-bóo nā tâng-sim; ka-hô } \\
\text { bān-sū hing } \\
\text { Collaborative husband and wife } \\
\text { makes a harmonious home }\end{array}$ \\
\hline $\begin{array}{l}\text { U-sim phah-thih thih sîng tsng; u-sim khui-suann } \\
\text { suann piàn hn̂g } \\
\text { Iron and mountain can be village and farm, if } \\
\text { willing } \\
\text { Tsit-ki tsháu tsit-tiám lòo; ū phah-piànn tióh-ū } \\
\text { tsiân-tôo } \\
\text { Each blade of grass begets a dew, great effort } \\
\text { begets the future } \\
\text { Ka-kī tsìng tsit-tsâng; khah-iânn khuànn pát-lâng } \\
\text { Grow it in the lawn; nothing next door we yearn }\end{array}$ & $\begin{array}{l}\text { Sian-lâng phah-kóo ū-sîtshò; } \\
\text { kha-pōo táh-tshò siánn-lâng bô } \\
\text { Deities might miss a drum beat; } \\
\text { human may miss a step }\end{array}$ \\
\hline
\end{tabular}


In his discussion on super-diversity in the $21^{\text {st }}$ century, Li (2018, pp. 14-15) reminds us that we are dealing with a post-multilingualism challenge:

where simply having many different languages is no longer sufficient either for the individual or for society as a whole, but multiple ownerships and more complex interweaving of languages and language varieties, and where boundaries between languages, between languages and other communicative means, and the relationship between language and the nation-state are being constantly reassessed, broken, or adjusted by speakers on the ground.

Widening the dialectic framework to include the Hokkien proverbs is a translanguaging move (cf. Cummins, 2017; Garcia \& Lin, 2017). Translanguaging, as Garcia (2017) puts it, is a bilingual mechanism that actuates and uses linguistic features from different languages available in the bilingual speaker's repertoire, for personal meaning-making, and interpersonal communication with others. A translanguaging move exploiting the Hokkien proverbs makes good common sense if we agree with Li (2018) that "multilinguals do not think unilingually in a politically named linguistic entity, even when they are in a 'monolingual mode' and producing one namable language only for a specific stretch of speech or text" (p. 18). In a multilingual Singapore, the understanding of certain Hokkien values, by means of translanguaging, may be the relevant pragmatics for boosting aspiration and mutual appreciation. For a start, adaptation of the Hokkien wise sayings into the performing discourse may commence in the local musical scenes such as the getai as well as the musical performances in the Malay month and Mandarin week celebration, respectively. Hokkien proverbs may also be integrated into the theme songs of television series. A Mandarin drama serial with the theme song such as "Kang-hu kàu-tshù; beh-iōng tióh-ü" (Be prepared for future), for example, may inspire the viewers to engage in skills upgrading and self-improvement courses.

\section{Conclusion}

Despite its status as a diminishing dialect, and a former lingua franca, research on Singapore Hokkien receives little in-depth attention. The heritage status of Hokkien may eventually become a historical memory if there is no intervention to slow the Hokkien language shift in Singapore. Regardless of the future outcomes, Hokkien ethnocultural schemata advance a mindset cognisant of self-improvement towards the common good. In addition, incorporating the Hokkien proverbs by means of translanguaging to enhance the curriculum of civic and national education may pave the way for boosting sociocultural values. It is possible for Hokkien to invigorate the national education, thus, advancing a diversified perspective on citizenry in the nation building road map, because an added layer of positive values may amplify and beautify the narrative one people in Singapore. 


\section{Acknowledgement}

A version of this paper was read at the $16^{\text {th }}$ Malaysia Singapore Forum, University of Malaya, 19-20 September 2018. The National University of Singapore, and University of Malaya have rendered generous support to me. I am grateful to two anonymous reviewers for their constructive comments, especially to one of them who supplied the conventional romanisation of the Hokkien proverbs. The remaining errors therein are solely mine.

\section{References}

Ang, P. (2017, Jun 10). Singapore talking: Presenting the news in Chinese dialects. The Straits Times. Retrieved August 2, 2020 from https://www.straitstimes.com/singapore/presenting-the-news-in-chinesedialects

Chia, L. (2018, Mar 5). National Education in schools to be refreshed: Janil Puthucheary Channel News Asia Retrieved May 8, 2018, from https://www.channelnewsasia.com/news/singapore/national-education-inschools-to-be-refreshed-janil-puthucheary-10014546

Chua, B. H. (2012). Structure, audience and soft power in East Asian pop culture. HK: Hong Kong University Press.

Cummins, J. (2017). Teaching for transfer in multilingual school contexts. In 0 . García, A. M. Y. Lin \& S. May (Eds.), Bilingual and Multilingual Education (pp. 103115). Cham: Springer.

Daipi, M. N. (2018). Siri Sembang Munsyi: Peribahasa. Kuala Lumpur: Dewan Bahasa dan Pustaka.

Dept. of Statistics, Singapore. (2010). Census on population. Retrieved May 10, 2018, from http://www.singstat.gov.sg/publications/publications-and papers/cop2010/census10_stat_release1

Garcia, O. (2017, Oct. 17). Translanguaging. The multilingual \& diversity lecture. Retrieved August 4, 2020, from https://www.youtube.com/watch?v=511CcrRrck0

Garcia, O., \& Lin, A. M. Y. (2017). Translanguaging in bilingual education. In O. García, A. M. Y. Lin \& S. May (Eds.), Bilingual and Multilingual Education (pp. 117130). Cham: Springer.

Gibbs, R. W. Jr. (1994). The poetics of mind: Figurative thought, language, and understanding. New York: Cambridge University Press.

Heine, B. (1997). Cognitive foundations of grammar. New York: Oxford University Press.

Kuan, E. (2014). My pictorial book of dialect: Idioms \& slangs. Singapore: Sibey Nostalgic.

Lakoff, R. T. (2005). Civility and its discontents: Or, getting in your face. In R. T. Lakoff \& S. Ide (Eds.), Broadening the Horizon of Linguistic Politeness (pp. 23-43). Amsterdam: John Benjamins.

Lee, C. L. (2016). Grandmother's tongue: Decline of Teochew language in Singapore. In W. Li (Ed.), Multilingualism in the Chinese diaspora worldwide: Transnational connections and local social realities (pp. 196-215). New York: Routledge. 
Li, W. (2018). Translanguaging as a practical theory of language. Applied Linguistics 39(1), 9-30.

Liew, K. K., \& Chan, B. (2013). Vestigial pop: Hokkien popular music and the cultural fossilization of subalternity in Singapore. Sojourn: Journal of Social Issues in Southeast Asia, 28(2), 272-298.

Malcolm, I. G. (2007). Cultural linguistics and bidialectal education. In F. Sharifian \& G. B. Palmer (Eds.), Applied cultural linguistics (pp. 53-63). Amsterdam: John Benjamins.

Mathew, M. (2017). Introduction: Ethnic diversity, identity and everyday multiculturalism in Singapore. In M. Matthew (Ed.), The Singapore ethnic mosaic: Many cultures, one people (pp. xi-xli). Singapore: World Scientific.

Ministry of Culture, Community and youth. (2018). Vision, mission and values. Retrieved June 27, 2018, from https://www.mccy.gov.sg/About-us.aspx

Nayak, S., \& Rao, M. (2013). Singapore proverbs. Singapore: Booksmith Productions.

Nolan, K. (2004). The power of language: A critique of the assumptions and pedagogical implications of Horward Gardner's concept of linguistic intelligence. In J. L. Kincheloe (Ed.), Multiple Intelligences reconsidered (pp. 31-48). New York: Peter Lang.

Pennycook, A. (2007). Global Englishes and transcultural flows. London: Routledge.

Puah, Y. Y., \& Ting, S. H. (2017). Dominant language-ethnicity notions of the Malaysian Chinese in Sarawak: Paternity or patrimony? Asian Studies Review, 41(1), 79-98.

Salleh, M. H. (2018). Pantun: The poetry of passion. Kuala Lumpur: University of Malaya.

Salleh, M. H. (1991). Yang empunya cerita: The mind of the Malay author. Kuala Lumpur: Dewan Bahasa dan Pustaka.

Sew, J. W. (2016, Nov. 1). Singapore Hokkien: The return of the repressed. NUSINALCO Symposium: Common Languages in Asia, AS7, National University of Singapore.

Sew, J. W. (2015a). Cultural literacy in Chinese and Malay. WORD, 61(2), 165-177.

Sew, J. W. (2015b). Aspects of cultural intelligence in idiomatic Asian cultural scripts. WORD. 61(1), 12-24.

Sew, J. W. (1997). Power pragmatics in Asian languages. Language Sciences, 19(4), 357-367.

Sew, J. W. (1996). Symbolisation in Malay: Evidence in genre and lexicon. The Fourth International Symposium on Language and Linguistics. Salaya, Thailand: Mahidol University Press.

Singtel. (2014, Feb. 3). Are you Hokkien? (你是福建人吗?) Episode 1. Retrieved May 8, 2018, from https://www.youtube.com/watch?v=uoUWCZsvYMI

Ting, S. H., \& Puah, Y. Y. (2015). Sociocultural traits and language attitudes of Chinese Foochow and Hokkien in Malaysia. Journal of Asian Pacific Communication, 25(1), 117-140.

Ting, S. H., \& Puah, Y. Y. (2010, June). Language attitudes of Hokkien speakers towards Hokkien and Mandarin. Paper presented at the Borneo International Conference on Language and Literature (BiCOLL), "Unity in Diversity", Kuching, Sarawak. 
Wee, L. (2006). The semiotics of language ideologies in Singapore. Journal of Sociolinguistics, 10(3), 344-361.

Wee, L. (2011). Language without rights. New York: Oxford University Press.

Wee, L. (2018). Essentialism and language rights. In L. Lim, C. Stroud \& L. Wee (Eds.), The multilingual citizen: Towards a politics of language for agency and change (pp. 40-64). Bristol: Multilingual Matters.

冰冰 Show. (2017，Nov. 23). 第 132 集一又見天天開心 (司馬玉嬌、長青). Retrieved May 7, 2018, from https://www.youtube.com/watch?v=afrCdY84SSA

冰冰 Show. (2017, Dec. 07). 第142 集一蘋果歌后 楊燕 (楊燕、倪實). Retrieved May 7, 2018, from https://www.youtube.com/watch?v=wCLRBnf6gvA

冰冰 Show. (2017, Dec. 15). 第148 集一舊皮箱的流浪兒 郭一男(郭一男、七郎、 林良歡 ). Retrieved May 8, 2018, from https://www.youtube.com/watch?v=E7VWmNrSr1o

冰冰 Show. (2017, Nov. 20). 第129 集一蘇宥蓉陳怡婷 慕鈺華. Retrieved May 8, 2018, from https://www.youtube.com/watch?v=AQyPRW_M-c8

冰冰 Show. (2017, Nov. 17). 蔡佳麟 冰冰 show--車頂水姑娘. 青蚵嫂, 乎我醉. Retrieved May 9, 2018, from https://www.youtube.com/watch?v=8YRykAAuWdQ

冰冰 Show. (2017, Dec. 04). 第139 集一你是我的眼 蕭煌奇 (吳申梅、蕭煌奇). $\begin{array}{llll}\text { Retrieved May } & \text { 10, } & \text { from }\end{array}$ https://www.youtube.com/watch?v=jROWoONQYI

冰冰 Show. (2017, Dec. 21). 第152 集一藝界大哥大-馬如龍(馬如龍、黃鐙輝、吳 勇 濱 ). Retrieved May 15, 2018 from https://www.youtube.com/watch?v=80zU1mBPwOw

冰冰 Show. (2016, Dec. 27). 第156 集一演藝路小子難縤(陳子強、顔正國、曾治 豪 ). Retrieved May 20, 2018 from https://www.youtube.com/watch?v=c3icsu8EqY4

冰冰 Show. (2017, Dec. 18). 第149 集一念歌國寶楊秀卿(楊秀卿、許效舜、儲見 智 ). Retrieved June 12, 2018 from https://www.youtube.com/watch?v=grpfbQwYpQQ 冰冰 Show. (2017, Dec. 11). 第144 集一拚自己的舞台 (馮偉傑、梁佑南、 王 彩 ). Retrieved June 15, 2018 from https://www.youtube.com/watch?v=KLZa_ZKbpyw

冰冰 Show. (2017, Dec. 19). 第 150 集一台灣媽祖 侯麗芳 (侯麗芳、蕭惠). Retrieved June 20, 2018 from https://www.youtube.com/watch?v=AWPZXOSA8k

冰冰 Show. (2017，Dec. 13). 第146 集一歌團神鵰俠侣 (康雷、張䲨). Retrieved June 22, 2018 from https://www.youtube.com/watch?v=286jHbeVFb4

中視新聞. (2018, Jan. 26) 午間綜藝收視率逼近 1 白冰冰: 破天荒|中視新聞 20180126. Retrieved August 3, 2020 from https://www.youtube.com/watch?v=OvjxMikX_Uc 